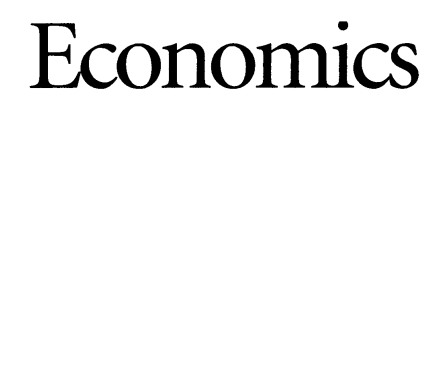




\section{Macmillan Foundations}

A series of introductory texts across a wide range of subject areas to meet the needs of today's lecturers and students

Foundations texts provide complete yet concise coverage of core topics and skills based on detailed research of course requirements suitable for both independent study and class use - the firm foundations for future study.

\section{Published}

\section{Biology}

Chemistry

Economics

Physics

Politics

\section{Forthcoming}

History of English Literature

Mathematics for Science and Engineering

Modern British History

Modern European History

Nineteenth Century Britain

Psychology 


\section{Economics}

CHRIS MULHEARN and

HOWARD R. VANE

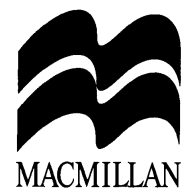


(C) Chris Mulhearn and Howard R. Vane 1999

All rights reserved. No reproduction, copy or transmission of this publication may be made without written permission.

No paragraph of this publication may be reproduced, copied or transmitted save with written permission or in accordance with the provisions of the Copyright, Designs and Patents Act 1988, or under the terms of any licence permitting limited copying issued by the Copyright Licensing Agency, 90 Tottenham Court Road, London W1P 9HE.

Any person who does any unauthorised act in relation to this publication may be liable to criminal prosecution and civil claims for damages.

The authors have asserted their rights to be identified as the authors of this work in accordance with the Copyright, Designs and Patents Act 1988.

First published 1999 by

MACMILLAN PRESS LTD

Houndmills, Basingstoke, Hampshire RG21 6XS

and London

Companies and representatives

throughout the world

ISBN 978-0-333-69183-0

ISBN 978-1-349-14437-2 (eBook)

DOI 10.1007/978-1-349-14437-2

A catalogue record for this book is available from the British Library.

This book is printed on paper suitable for recycling and made from fully managed and sustained forest sources.

$\begin{array}{cccccccccc}10 & 9 & 8 & 7 & 6 & 5 & 4 & 3 & 2 & 1 \\ 08 & 07 & 06 & 05 & 04 & 03 & 02 & 01 & 00 & 99\end{array}$




\section{Contents}

Preface

Acknowledgements

\section{Economics and the Economy}

1.1 Introduction

1.2 The market versus the state as an allocator of resources

1.3 Scarcity, choice and opportunity cost

1.4 The historical development of economic thought and its contemporary relevance

Adam Smith

Smith's relevance today

Classical economics

Ricardo's relevance today

The Keynesian revolution

The contemporary relevance of Keynes

The re-emergence of market perspectives 20

The real-world application of modern market perspectives

Reflections on the history of economics

Summary

Key terms

Self-test questions

Questions for discussion

Further reading

Using the Internet to study economics Internet links

\section{The Market}

\subsection{Introduction}

2.2 Consumers and demand

The prices of other goods and services

The preferences or tastes of consumers
2.3 Producers and supply

2.4 The market: bringing demand and supply together

The equilibrium price and market equilibrium

Changes in the equilibrium price and market equilibrium

2.5 Applying market analysis: the example of economic integration in the European Union

Concluding remarks

Summary

Key terms

Self-test questions

46

Questions for discussion

46

Further reading

Internet links

\section{Markets and Economic Efficiency}

3.1 Introduction

3.2 The market and socially efficient production

Demand and marginal utility

Supply and marginal cost

Marginal social cost and marginal social benefit

3.3 Producer surplus

3.4 Consumer surplus

3.5 Applying producer and consumer surplus

3.6 Elasticity in the market 58

3.7 Price elasticity of demand 58 
3.8 Determinants of price elasticity of demand

The availability of substitutes

The proportion of income spent on a good or service

Time

3.9 Applying price elasticity of demand

3.10 Other forms of elasticity

Income elasticity of demand

Applying income elasticity of demand

Price elasticity of supply

Determinants of price elasticity of supply

Summary

Key terms

Self-test questions

Questions for discussion

Further reading

\section{The Producer}

4.1 Introduction

4.3 Why are firms necessary?

Savings on transaction costs

The capacity of firms to extend the division of labour

The potential of firms to innovate

4.4 Different kinds of firm

The relative advantages and disadvantages of different forms of ownership

4.5 Firms and entrepreneurship: an Austrian view

4.6 Firms and the principal-agent problem

Key terms
4.2 What do firms do?

Further reading

Internet links

\section{Market Structures}

5.1 Introduction

5.2 Market structures $\quad 84$

5.3 Perfect competition $\quad 87$

The perfectly competitive firm as a price taker

The revenue curves of the perfectly competitive firm

The cost curves of the firm

The profit-maximizing output decision

90

The short-run position of the perfectly competitive firm

The long-run position of the perfectly competitive firm

The perfectly competitive firm and allocative efficiency

Perfect competition: a summary

\subsection{Monopoly}

Sources of monopoly power

5.5 The economic implications of monopoly

The monopolist's cost and revenue curves

The monopolist's output decision

Monopoly and allocative efficiency

Reflections on monopoly

Government control of monopoly

100

\subsection{Imperfect competition and} oligopoly

Imperfect competition

102

Oligopoly

5.7 Market structures: an institutionalist view

Summary

Key terms

Self-test questions

Questions for discussion 109

Further reading

Internet links 
6 Market Failure Versus Government Failure

110

6.1 Introduction

6.2 Market failure

6.3 Public goods

6.4 Externalities

Negative externalities

Positive externalities

6.5 Externalities and the welfare state 117

6.6 The liberal view: market failure and state failure

State failure

State failure versus market failure

Market failure in the liberal view

Liberalism: a summary

6.7 Privatization

The rationale for privatization

The case against privatization

Summary

Key terms

Questions for discussion

Further reading

Internet links

\section{Factor Markets}

\subsection{Introduction}

7.2 The labour market

7.3 The demand for labour

The firm's demand for labour in the short run

The firm's demand for labour in the long run

7.4 The supply of labour

The supply of labour in an economy The individual's supply of labour

The supply of labour to a particular occupation

The elasticity of labour supply

7.5 Issues in the labour market: bringing demand and supply together

119

120

121

121

122

123

124

125

125

126

126

126

128

128

129

133

133

135

135

135

138

139

139
Skilled and unskilled labour

140

Human capital

Minimum wages

143

146

7.6 Factor incomes and economic rent

Summary

151

Key terms

152

Self-test questions

152

Questions for discussion

153

Further reading

153

Internet links

154
8 Distribution of Income 155

8.1 Introduction 155

8.2 Measuring the distribution of personal incomes

156

8.3 Measuring inequality in the distribution of personal incomes 157

8.4 Sources of inequality 160

8.5 Government policy and redistribution

8.6 Concluding remarks

Summary

164

Key terms

165

Self-test questions

165

Questions for discussion

166

Further reading

166

9 The Objectives of Macroeconomic Policy 167

9.1 Introduction 167

9.2 Economic growth 168

9.3 Unemployment 171

9.4 Inflation 174

9.5 The balance of payments 178

9.6 A brief overview of macroeconomic policy since 1945181 
Summary

184

Key terms

Self-test questions

Questions for discussion

Further reading

Internet links

\section{Economic Growth}

10.1 Introduction

10.2 Measuring economic growth

10.3 Real GDP, living standards and welfare

10.4 The Solow growth model The aggregate production function The steady state

10.5 The new endogenous growth models

10.6 Concluding remarks

Summary

Key terms

Self-test questions

Questions for discussion

Further reading

11 Unemployment: Causes and Cures

11.1 Introduction

11.2 The classical approach

11.3 The orthodox Keynesian approach

The equilibrium level of national income in the Keynesian model

11.4 The monetarist approach

11.5 The new classical approach

11.6 The new Keynesian approach

Efficiency wage model

Insider-outsider model

Hysteresis effects and unemployment
184

185

186

186

186

187

187

187

191

191

193

196

197

198

198

199

199

200

201

201

202

203

207

210

212

212

213

214

214
11.7 Unemployment in Europe

Summary

219

Key terms

219

Self-test questions

220

Questions for discussion

221

Further reading

221

Internet links

12 Inflation: Causes and Cures 222

12.1 Introduction

222

12.2 The monetarist view

The quantity theory of money: old and modern

The original Phillips curve

The expectations-augmented Phillips curve

Policy implications

229

Keynesians, monetarists and new classicists

Inflation as an international monetary phenomenon

234

12.3 The non-monetarist view

Policy implications

12.4 Concluding remarks

236

Summary

237

Key terms

237

Self-test questions

238

Questions for discussion

239

Further reading

239

Internet links

240

\section{Business Cycles: Causes and} Control

13.1 Introduction

13.2 Main features of business cycles

13.3 The Keynesian approach

13.4 The monetarist approach

13.5 The new classical approach 
13.6 The real business cycle approach 250

13.7 The political business cycle approach

251

13.8 Concluding remarks

Summary

Key terms

Self-test questions

Questions for discussion

Further reading

Internet links

\section{Stabilizing the Economy}

14.1 Introduction

14.2 Discretionary policy and policy rules

14.3 The Keynesian view

14.4 The monetarist view

14.5 The new classical view

Policy ineffectiveness proposition

Time inconsistency

Lucas critique

14.6 The real business cycle view

14.7 Concluding remarks

Summary

Key terms

Self-test questions

Questions for discussion

Further reading

Internet links

\section{International Trade}

15.1 Introduction

The advantages of trade

The economic basis for trade

271

Some negative consequences of trade

272

15.2 The theory of comparative advantage
15.3 Reflecting on comparative advantage: further developments in trade theory

15.4 Patterns of trade since $1945 \quad 279$

15.5 International trade policy 283

Understanding protectionism 283

The institutions of international trade policy: from GATT to the WTO 286

Summary 289

Key terms 290

Self-test questions 290

Questions for discussion 291

Further reading 291

Internet links 291

16 The Balance of Payments and Exchange Rates

16.1 Introduction

293

16.2 The balance of payments accounts

Influences upon the current and capital accounts

Disequilibria in the balance of payments

The balance of payments performance of selected economies

16.3 Exchange rates

16.4 Exchange rate determination 302

16.5 Exchange rate systems 306

Flexible exchange rates $\quad 306$

Fixed exchange rates $\quad 307$

Managed rates

16.6 Exchange rate systems in practice

The Bretton Woods system

The non-system

The European exchange rate mechanism (ERM)

16.7 Currency speculation and exchange rate systems 
16.8 European Monetary Union

Summary

Key terms

Self-test questions

Questions for discussion

Further reading

Internet links

\section{Issues in the International}

\section{Economy}

17.1 Introduction

17.2 The international or the 'global' economy?

17.3 International trade: a global process?

17.4 A 'globalized' foreign exchange market?

17.5 Transnationals and 'globalization'

17.6 The origins of the globalization thesis

\section{Answers to Self-Test Questions} 332

Glossary

332

Bibliography

334 Index
17.9 Promoting development: the state versus the market 


\section{Preface}

TODAY foundation courses in economics are taught on a wide range of undergraduate degree programmes. First-year students reading for a single honours degree in economics are fortunate in that they can turn to a number of well-established and respected introductory textbooks covering the core material. Examples include: Begg, Fischer and Dornbusch (1997); Lipsey and Chrystal (1995); Parkin, Powell and Matthews (1997); and Sloman (1998). These books, however, tend to be less well received by students who are studying economics as part of broader degree programmes in areas such as Social Studies and Combined Studies. Students on such degree programmes are often intimidated by the sheer length of the specialist texts and a style or approach that relies heavily on diagrammatic presentation and frequently uses algebraic/mathematical notation.

The main aim of the present book is to meet the needs of non-specialist students taking an introductory course in economics by providing a rigorous yet concise coverage of the core material in a user-friendly and accessible fashion. The book should also prove useful to specialist students in highlighting the central issues addressed in some of the more voluminous texts currently on the market.

The book is organized as follows. At the start of each chapter a set of questions indicates the main issues to be addressed. As they are introduced, key terms and concepts are highlighted in the text and defined in the margin. Examples of actual economic problems and phenomena are presented in boxes so that the reader can verify the immediate relevance of the analysis under consideration and confirm his or her understanding of it. Frequent cross-references are also made to material covered in other chapters so that the reader can see important links between the different aspects of economics. Each chapter ends with a summary of the main issues discussed; a list of key terms; a set of self-test questions (where appropriate); questions for discussion; and, again where appropriate, suggestions for further reading and links to the Internet. Answers to the self-test questions, a glossary and a brief bibliography can be found at the end of the book.

The book is structured around two key themes. In its treatment of microeconomic material, there is an emphasis on the question of the appropriate role of the state in a modern economy. There is a tendency for specialized texts to dwell on the theoretically derived efficiency advantages of the market; this begs the question of why, in reality, there is such a weight and variety of state intervention. The book seeks to provide answers in respect of a range of microeconomic issues. The second theme interprets the macroeconomic issues as a series of problems that require elaboration as to their nature, their (competing) underlying explanations, and the range of policy options available for their resolution. The two themes are explicitly linked by their emphasis on the issue of public policy. In taking this approach we hope to demystify economics for non-specialist students and to aid their understanding of how economic analysis can be applied to 'real world' issues. 
We should like to express our gratitude to a friend and colleague Steve Smith, who read and made a number of helpful and incisive comments on Chapters 1-8 and 10. We are also grateful for the helpful comments made by the anonymous reviewers used by Macmillan. However, above all, our thanks go to our families, who have been a constant source of support to us and to whom this book is dedicated. 


\section{Acknowledgements}

Grateful acknowledgement is made to the following for permission to use copyright material:

The Boston Consulting Group for Box 7.2 from Financial Times, 10 February 1997.

Cambridge University Press for Table 8.3 from P. Gregg and S. Machin, 'Is the UK rise in inequality different?', in R. Barrell, The UK Labour Market (1994).

Financial Times Syndication Department for Box 1.5 from Financial Times, 16 April 1998; Box 1.6 from Financial Times, 5 July 1994; Box 2.2 from Financial Times, 19 November 1997; Box 2.4 from Financial Times, 15 February 1996; Box 5.1 from Financial Times, 21 December 1996; Box 6.2 from Financial Times, 16 January 1997; and Box 7.3 from Financial Times, 29 April 1997.

Guardian Syndication Department for Box 3.1 from The Guardian, 8 April 1996; Box 15.1 from The Guardian, 13 September 1996; and Box 17.2 from The Guardian, 10 September 1997.

HMSO for Box 7.1 from HM Treasury, Employment Opportunity in a Changing Labour Market, 27 November 1997; and Table 16.7 from UK Treasury.

The Independent Newspaper Publishing plc for Box 1.2 from The Independent, 14 November 1994; Box 2.1 from The Independent, 5 February 1997; and Box 6.1 from The Independent, 6 August 1996.

OECD for data for Table 1.2 from OECD Health Data, 1960/1995 (1997); Figure 7.4 from OECD Jobs Study (1994); Tables 15.5 and 15.6 from Main Developments in Trade (1995); Table 17.2 from OECD Economic Survey: Korea 1993/1994 (1994); Tables 9.2, 9.3, 11.1, 16.5 and 16.6 and Figure 11.9 from data in various issues of OECD Economic Outlook.

Office for.National Statistics for Table 4.1 from Business Monitor PA1003; Tables 7.1, 8.5, 8.6 and 8.7 from Economic Trends (March 1997); Tables 8.1, 8.2 and 8.4 from Economic Trends (November 1987); Table 9.5 from Economic Trends; Table 7.2 and Figure 7.9 from Labour Market Trends (November 1997); and Table 16.3 from UK Economic Accounts (1994); all @ Crown Copyright.

Oxford University Press for Box 17.1 and Table 17.3 from data in Human Development Report 1997, United Nations Development Programme.

Routledge for Table 6.1 from S. Martin and D. Parker, The Impact of Privatization (1997); and Table 17.1 from J.H. Dunning, Explaining International Production (1988).

The Scotsman Publications Limited for Box 6.4 from The Scotsman, 1 July 1997.

Tony Snape for Box 2.3 from The European, 30 May 1996. 
Photographs and cartoons

Camera Press, p. 79; f8 Imaging, pp. 34, 44, 74, 103, 114, 271, 320, 333; Hulton Getty, pp.14, 18; PA News, pp. 168, 218; Private Eye, pp. 106, 115, 130, 141, 155, 188, 318, 321; Royal Mint, p. 224; Small Print, p. 243; Topham Picturepoint, pp. 9, 21, 81; University of Chicago News Office, p. 265.

Every effort has been made to trace all the copyright holders, but if any have been inadvertently overlooked the publishers will be pleased to make the necessary arrangement at the first opportunity. 